\title{
LOCAL FOOD ENJOYMENT AND CUSTOMER DELIGHT: KEYS TO REVISIT INTENTION
}

\author{
Risma Jayanti Paramita1, Chairy Chairy ${ }^{2 *}$, Jhanghiz Syahrivar ${ }^{3}$ \\ ${ }^{1}$ School of Business, President University, Bekasi, Indonesia \\ Email: rismajayantii13@gmail.com \\ ${ }^{2}$ School of Business, President University, Bekasi, Indonesia \\ Email: chairy@president.ac.id \\ ${ }^{3}$ School of Business, President University, Bekasi, Indonesia \\ Institute of Marketing, Corvinus University of Budapest, Budapest, Hungary \\ Email: jhanghiz@president.ac.id \\ *penulis korespondensi
}

Masuk : 13-09-2020, revisi: 26-09-2021, diterima untuk diterbitkan : 28-09-2021

\begin{abstract}
ABSTRAK
Jawa Tengah telah lama dikenal sebagai salah satu pusat pertumbuhan ekonomi di Indonesia. Salah satu kota terbesar di kawasan ini, juga dikenal sebagai salah satu tujuan wisata paling populer di tanah air, adalah Yogyakarta. Penelitian ini bertujuan untuk mengetahui peran kenikmatan makanan lokal dan sukacita pelanggan terhadap niat berkunjung kembali wisatawan Yogyakarta, khususnya kawasan Malioboro. Penelitian kuantitatif ini menggunakan purposive sampling; kuesioner online disebarkan kepada 193 pengunjung Malioboro, Yogyakarta. Penelitian ini menggunakan PLS-SEM untuk menganalisis data. Hasil dari penelitian ini mengungkapkan bahwa: 1) Kenikmatan makanan lokal memiliki pengaruh positif terhadap sukacita konsumen 2) Kenikmatan makanan lokal memiliki pengaruh positif terhadap niat berkunjung kembali 3) Sukacita konsumen memiliki pengaruh positif terhadap niat berkunjung kembali dan 4) Sukacita konsumen memediasi hubungan antara kenikmatan makanan lokal dan niat berkunjung kembali. Wisata kuliner melalui promosi makanan lokal dapat dimanfaatkan untuk meningkatkan ketahanan masyarakat lokal di masa pandemi COVID-19.
\end{abstract}

Kata Kunci: Kenikmatan Makanan Lokal, Sukacita Konsumen, Niat Berkunjung Kembali, Turisme

ABSTRACT

Central Java has long been known as one of the centres of economic growth in Indonesia. One of the largest cities in the region, also known as one of the most popular tourist destinations in the country, is Yogyakarta. This research aimed to investigate the role of local food enjoyment and customer delight on tourists' revisit intentions to Yogyakarta, especially the Malioboro area. This quantitative research used purposive sampling; online questionnaires were distributed to 193 visitors of Malioboro, Yogyakarta. This study utilized PLS-SEM to analyse the data. The results of this research reveal that: 1) Local food enjoyment has a positive effect on customer delight 2) Local food enjoyment has a positive effect on revisit intention 3) Customer delight has a positive effect on revisit intention and 4) Customer delight mediates the relationship between local food enjoyment and revisit intention. Culinary tourism, which promotes local foods, has the potential to improve local community resilience during the COVID-19 pandemic.

Keywords: Local Food Enjoyment, Customer Delight, Revisit Intention, Tourism

\section{INTRODUCTION}

The tourism industry around the world, including Indonesia, has been impacted by the COVID-19 pandemic. Irregular buying patterns, such as panic buying, are reported everywhere during the pandemic, creating certain domestic uncertainties (Syahrivar et al., 2021). With the occasional lockdown and closure of shopping places, countries that rely heavily on incomes from tourism are struggling to recover. Yogyakarta, Indonesia, was one of the hardest hit by the pandemic, as evidenced by the decline in tourist numbers (Purnomo et al., 2021). Immediate strategies are needed to identify the key factors or elements in tourist revisit intention. One of the strategies may 
be related to a so-called "culinary tourism" via the introduction of local foods and the cultures behind them (Horng \& Tsai, 2010).

Yogyakarta is located in Central Java, Indonesia. Apart from being one of the famous tourist destinations in the country, it is also known as a student city or a city of scholars (Sambodo \& Utami, 2019). Yogyakarta is rich in cultural heritages, such as arts and architecture, and the city is relatively preserved (Rianingrum, Sachari, \& Widodo, 2014). Another distinct aspect of Yogyakarta is its unique and tasty local foods (Yusuf, 2017; Purnomo et al., 2021), such as Gudek, Kipo, and Geplak. A previous study by Arsil, Li and Bruwer (2014) who took their samples, among others, in Yogyakarta, suggests that "local" foods were perceived to be cheaper but better in terms of quality compared to "national" foods and "imported" foods.

Various factors influence the decision to revisit certain tourism places, such as Yogyakarta. Islamiyati and Chairy (2021) found that a memorable shopping experience was a positive predictor of revisit intention to Yogyakarta. In the context of Bali, another famous tourism place in the country, Adrianty and Chairy (2021) found that aesthetic experiences improved revisit intention. A specific tourist experience gaining more attention in the tourism literature is a positive and pleasant surprise. Exceeding customers' expectations is of paramount importance in the tourism industry. Surprise elements to bring about memorable tourism experiences is pivotal in the overall strategies to attract tourists.

This research aimed to investigate factors influencing tourist revisit intention to Yogyakarta, particularly an area called Malioboro. Two interesting concepts have been identified, namely local food enjoyment and customer delight. Previous studies suggest that tourists were attracted to revisit a tourist destination because of some positive experiences or memories regarding the local foods (Crotts, Pan, \& Raschid, 2008; Jung et al., 2015; Chairy \& Syahrivar, 2019). Customer delight, or a pleasant surprise that goes beyond typical marketing offerings, has also been shown to have a key influence in revisit intentions (Oliver, Rust, \& Varki, 1997; Ji \& Prentice, 2021). Therefore, this research tested the possible linkages of local food enjoyment, customer delight and revisit intention in the context of Yogyakarta.

\section{LITERATURE REVIEW}

\section{Local food enjoyment}

Food is one of the manifestations of local cultures and heritages (Chairy \& Syahrivar, 2019; Wijaya, 2019). Local foods also reflect the richness, as well as the uniqueness, of natural and biological resources in an area where local people depend on for a living (Nakamura \& Hanazaki, 2017). Unique local foods can also be used to attract domestic and international tourists (Jung et al., 2015; Chairy \& Syahrivar, 2019), thereby improving the well-being of local communities. A previous study by Kim, Eves and Scarles (2009) suggests that tourists enjoyed local foods because they gave exciting and authentic experiences and built togetherness when shared during the trips. Local foods, how the ingredients are procured and how they are produced and delivered to consumers, should be managed well by the local government and community so that they can contribute to local community resilience and improve the local pride (McDaniel, Soto Mas, \& Sussman, 2021). Unmanaged local food systems may contribute to national food waste and environmental pollution (Dusoruth, Peterson, \& Schmitt, 2018; Chairy et al., 2020). In this study, local food enjoyment is defined as the degree to which people enjoy tasting and sampling a variety of local foods, as well as participating in local food events. 


\section{Customer delight}

Customer delight is conceptually distinct from customer satisfaction. While customer satisfaction is about exceeding customers' expectations with regards to product performance, customer delight is about providing 'a positive surprise' (Berman, 2005). The word 'surprise' naturally means that it is beyond customers' expectations. Oliver, Rust and Varki (1997) proposed three predictors of delight: surprising consumption, arousal and positive affect. They summed up delight as "Those services and products capable of providing pleasing unexpected performance." (p.330). To create a state of 'delight,' companies must supply features that go above customers' preconceived notions of how products and services should operate, to the point where these elements positively surprise them. While delivering the best hotel room services can only increase customer satisfaction, to surprise a guest with a birthday celebration should increase customer delight because it is beyond company's range of services or common expected features (McNeilly, \& Barr, 2006; Barnes, Collier, \& Robinson, 2014).

Previous studies on customer delight in tourism industries have included local foods elements. For instance, a previous study by Loureiro and Kastenholz (2011) in the context of rural lodging included "well presented and flavoursome" foods. The authors, however, did not directly test how local foods contributed to customer delight. In the hotel sector, Goswami and Sarma (2019) highlighted "special" cuisine as a part of efforts to create customer delight. Tsai and Wang (2017) argued that tourists attended local food-related activities or events to get "different experiences", instead of merely seeking food satisfaction. In this research, we argue that local foods, as a part of surprising consumption, may contribute to overall customer delight. Therefore, we formulated the second hypothesis as follows:

\section{$\boldsymbol{H}_{1}$ : Local food enjoyment has a positive effect on customer delight.}

\section{Revisit Intention}

Revisit intention roots in behavioural intention concept. Generally, behavioural intention refers to the probability of performing a specific action, hence a predictor of an actual behaviour (Ajzen \& Fishbein, 1980; Kim, Sun, \& Kim, 2013). Meanwhile, revisit intention is generally defined as the willingness to return and recommend a destination (Su et al., 2018). In the tourism context, this could include repurchasing tourism services or products or returning to tourist attractions.

Previous studies have shown that local food is one of the main motivations to revisit tourism spots. For instance, a previous study by Chairy and Syahrivar (2019) suggests that Bika Ambon was one of the driving factors for local and international tourists to (re)visit Medan, Indonesia. A previous study by Jung et al. (2015) in the context of local food festival demonstrated that local food enjoyment had a positive effect on revisit intention. A previous study by Crotts et al. (2008) suggests that sampling local foods was one of the key drivers of revisit intention. Positive experience on consuming local foods may evoke positive memories on tourist destinations. We argue that the desire to repeat the positive experience, such as consuming tasty local foods, and to relive the beautiful memories when visiting a tourist destination may lead to revisit intention. Therefore, we formulated our second hypothesis as follows:

\section{$\boldsymbol{H}_{2}$ : Local food enjoyment has a positive effect on revisit intention}

Oliver et al. (1997) proposed that (customer) delight was one of the antecedents of behavioural intention. An unexpected yet pleasant surprise experienced by customers during the service performance leads to the intention to repurchase a service in the future. A subsequent study by Finn (2005), however, suggested that the effect of delight on intention was "substantially 
weakened and no longer significant" (p. 111) after counting the measurement error. A previous study by Ji and Prentice (2021) in the context of casino resorts demonstrated that customer delight led to place attachment. Loureiro and Kastenholz (2011) found that delight had a positive and significant effect on loyalty (e.i. return intention as one of the indicators). A previous study by Kim, Vogt, and Knutson (2015) demonstrated a non-direct relationship between delight and conative loyalty (e.g. return intention) through cognitive and affective loyalty. In this research, we argue that experiencing customer delight during the trips may influence tourists' desire to return to Malioboro, Yogyakarta. Moreover, we also think that local food enjoyment may contribute to tourists' revisit intentions because they have a pleasant surprise element, hence delight. Therefore, we formulated our third hypothesis as follows:

$\mathrm{H}_{3 a}$ : Customer delight has a positive effect on revisit intention.

$\boldsymbol{H}_{3 b}$ : Customer delight mediates the relationship between local food enjoyment and revisit intention.

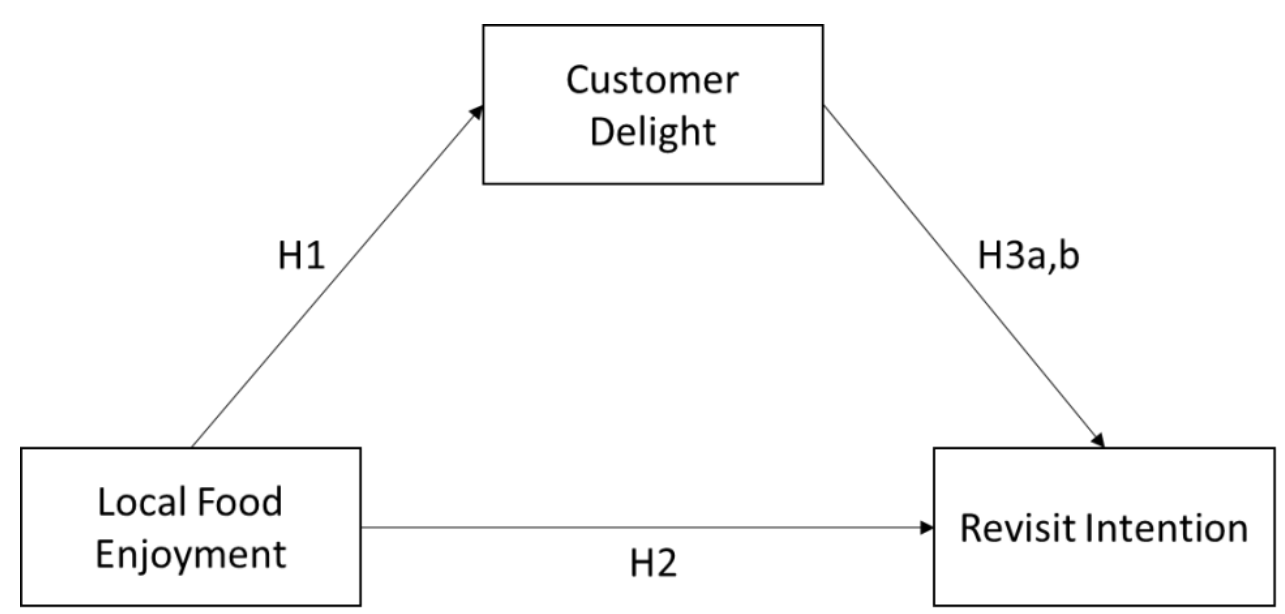

Figure 1. Theoretical Framework

\section{RESEARCH METHOD}

This quantitative research employed purposive sampling. To be eligible, respondents must have visited Yogyakarta. Table 1 shows that most of the respondents are male $(\mathrm{N}=108$ or $56 \%)$. The majority of the respondents are between $18-25$ years old $(\mathrm{N}=150$ or $78 \%)$. By occupations, most respondents are students $(\mathrm{N}=77$ or $40 \%)$ with senior high school education $(\mathrm{N}=82$ or $42 \%)$.

Table 1. Respondent Profile

\begin{tabular}{lcc}
\hline $\begin{array}{l}\text { Demographic } \\
\text { Gender : }\end{array}$ & Total & Percentage \\
Male & 108 & $56 \%$ \\
Female & 85 & $44 \%$ \\
\hline Age : & 150 & $78 \%$ \\
$\mathbf{1 8}-\mathbf{2 5}$ & 43 & $22 \%$ \\
$\mathbf{2 6 - 3 0}$ & & \\
\hline Education Background : & 82 & $42 \%$ \\
Senior High & 61 & $32 \%$ \\
Associate's Degree & 44 & $23 \%$ \\
Undergraduate & 6 & $3 \%$ \\
Post Graduate & & \\
\hline Occupation : & 77 & $40 \%$ \\
Student & &
\end{tabular}




\begin{tabular}{lcc}
\cline { 2 - 3 } Employee & 76 & $39 \%$ \\
Entrepreneur & 11 & $6 \%$ \\
Freelance & 16 & $8 \%$ \\
Other & 13 & $7 \%$ \\
\hline
\end{tabular}

The measurement scales and their reliabilities are shown in Table 2. A Pre-research involving 60 students indicate that Cronbach's Alpha of each scale is above 0.7 hence 'acceptable' (Taber, 2018).

Table 2. Measurement

\begin{tabular}{|c|c|c|c|}
\hline Variable & Items & Measures & Cronbach's Alpha \\
\hline $\begin{array}{l}\text { Local Food } \\
\text { Enjoyment } \\
\text { (X1) }\end{array}$ & $\begin{array}{l}\text { 1. I enjoy tasting a variety of } \\
\text { local foods. } \\
\text { 2. I enjoy sampling new and } \\
\text { different local foods. } \\
\text { 3. I enjoy tasting local foods } \\
\text { from different cultures. } \\
\text { 4. I enjoy tasting local foods } \\
\text { prepared by local people in } \\
\text { Yogyakarta. } \\
\text { 5. I enjoy exploring local foods } \\
\text { availability in Yogyakarta. } \\
\text { 6. I enjoy participating in local } \\
\text { food events and festivals. }\end{array}$ & $\begin{array}{l}\text { 5-Point Likert Scale } \\
(1=\text { Strongly } \\
\text { Disagree, } 5= \\
\text { Strongly Agree }) \\
\text { Likert Scale } \\
\text { Likert Scale }\end{array}$ & 0.851 \\
\hline $\begin{array}{c}\text { Customer Delight } \\
\text { (M) }\end{array}$ & $\begin{array}{l}\text { 1. I am much more satisfied with } \\
\text { Yogyakarta than I expected. } \\
\text { 2. I am delighted while visiting } \\
\text { Yogyakarta. } \\
\text { 3. I experienced a pleasant } \\
\text { surprise in Yogyakarta. }\end{array}$ & & 0.8 \\
\hline $\begin{array}{l}\text { Revisit Intention } \\
\text { (Y) }\end{array}$ & $\begin{array}{l}\text { 1. Yogyakarta will remain one } \\
\text { of my primary choices for } \\
\text { tourism. } \\
\text { 2. I may try to find out more } \\
\text { about tourist products and } \\
\text { services in Yogyakarta in the } \\
\text { future. } \\
\text { 3. I may visit Yogyakarta again } \\
\text { in the near future. } \\
\text { 4. I may keep in contact with the } \\
\text { people that I knew in } \\
\text { Yogyakarta for the next visit. } \\
\text { 5. I may visit the same } \\
\text { destinations located in } \\
\text { Yogyakarta again in the } \\
\text { future. } \\
\text { 6. I may stay longer in } \\
\text { Yogyakarta during my next } \\
\text { visit. }\end{array}$ & & 0.767 \\
\hline
\end{tabular}

To test the hypotheses, we employed Partial Least Square - Structural Equation Modelling or PLSSEM via SmartPLS 3.2.8 software. To analyse the results, we used the works of Henseler, Hubona, and Ray (2016) and Hair et al. (2019) as our primary guidelines. Several elements to report, such 
as Outer Loading Factor, Average Variance Extracted (AVE), Cronbach's Alpha, Composite Reliability, Coefficient of the Determinants (R2), and results of the hypotheses testing.

\section{RESULT AND DISCUSSION}

Table 3 demonstrates that all indicators of customer delight have outer loading factors greater than 0.7, indicating that they are acceptable. The majority of local food enjoyment indicators are more than 0.7, except one. Because one local food enjoyment indicator is less than 0.7 , it was excluded from future analysis. All indicators of revisit intention are greater than 0.7, indicating that they are acceptable.

Table 3. Outer Loading Factor

\begin{tabular}{l|ccc}
\multicolumn{5}{c}{ Table 3. Outer Loading Factor } \\
\cline { 1 - 2 } \multicolumn{1}{c}{$\begin{array}{c}\text { Customer } \\
\text { Delight }\end{array}$} & Local Food & $\begin{array}{c}\text { Revisit } \\
\text { Intention }\end{array}$ \\
CD1 & 0.842 & & \\
CD2 & 0.733 & & \\
\hline LF1 & 0.853 & & \\
LF2 & & 0.713 & \\
LF3 & & 0.650 & \\
LF4 & & 0.779 & \\
LF5 & & 0.713 & 0.768 \\
LF6 & & 0.802 & 0.716 \\
\hline RI1 & & 0.746 & 0.834 \\
RI2 & & & 0.817 \\
RI3 & & & 0.780 \\
RI4 & & & 0.735 \\
RI5 & & & \\
RI6 & & & \\
\hline
\end{tabular}

The discriminant validity test compares the value of each construct's square root of average variance extracted (AVE) to the correlation between the other constructs in the model; if the square root of AVE is greater than the correlation between all other constructs, the model has good discriminant validity. Recommended values are not less than 0.50 (See Table 4).

Table 4. AVE

\begin{tabular}{cc}
\multicolumn{2}{c}{ AVE } \\
\hline Customer Delight & 0.658 \\
Local Food & 0.586 \\
Revisit Intention & 0.603 \\
\hline
\end{tabular}

The Cronbach's Alpha and Composite Reliability of each variable are shown in Table 5. The results indicate that all variables are reliable. 
Table 5. Reliability Test

\begin{tabular}{lc}
\hline \multicolumn{2}{c}{ Cronbach's Alpha } \\
Customer Delight & 0.737 \\
Local Food & 0.822 \\
Revisit Intention & 0.867 \\
\hline \multicolumn{2}{c}{ Composite Reliability } \\
Customer Delight & 0.852 \\
Local Food & 0.876 \\
Revisit Intention & 0.901 \\
\hline
\end{tabular}

Figure 2 shows the final PLS-SEM model in this research. The R2 results indicate that $40.7 \%$ of variations in customer delight are accounted by the variables included in the model. The results also suggest that $50.9 \%$ of variations in revisit intention are accounted by the variables included in the model.

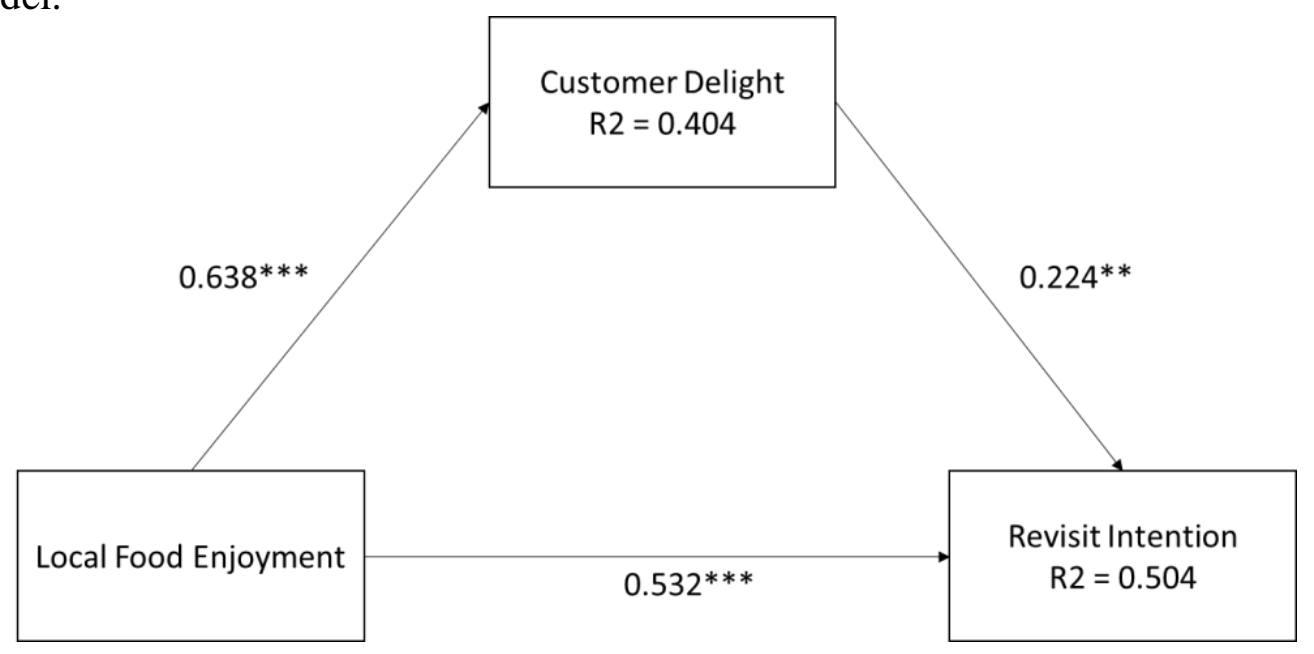

Figure 2. PLS-SEM Model $(* * *=p<.001, * *=.01)$

The hypotheses testing is presented in Table 6. The results indicate that all hypotheses can be supported.

Table 6. Hypothesis Testing

\begin{tabular}{|c|c|c|c|c|c|c|}
\hline & $\begin{array}{l}\text { Original } \\
\text { Sample } \\
(\text { O) }\end{array}$ & $\begin{array}{l}\text { Sample } \\
\text { Mean } \\
\text { (M) }\end{array}$ & $\begin{array}{l}\text { Standard } \\
\text { Deviation } \\
\text { (STDEV) }\end{array}$ & $\begin{array}{c}\text { T Statistic } \\
(\mid \text { O/STEER } \mid)\end{array}$ & P Values & Notes \\
\hline $\begin{array}{c}\text { Local Food } \rightarrow \\
\text { Customer Delight }\end{array}$ & 0.638 & 0.636 & 0.069 & 9.257 & 0.000 & $\begin{array}{c}\text { H1 is } \\
\text { supported }\end{array}$ \\
\hline $\begin{array}{c}\text { Local Food } \rightarrow \text { Revisit } \\
\text { Intention }\end{array}$ & 0.532 & 0.531 & 0.086 & 6.173 & 0.000 & $\begin{array}{c}\mathrm{H} 2 \text { is } \\
\text { supported }\end{array}$ \\
\hline $\begin{array}{c}\text { Customer Delight } \rightarrow \\
\text { Revisit Intention }\end{array}$ & 0.224 & 0.244 & 0.088 & 2.791 & 0.005 & $\begin{array}{c}\text { H3a is } \\
\text { supported }\end{array}$ \\
\hline $\begin{array}{c}\text { Local Food } \rightarrow \\
\text { Customer Delight } \\
\text { Revisit Intention }\end{array}$ & 0.156 & 0.156 & 0.062 & 2.526 & 0.012 & $\begin{array}{l}\text { H3b is } \\
\text { supported }\end{array}$ \\
\hline
\end{tabular}

Our research is able to prove that local food enjoyment has a positive effect on customer delight (H1). Previous studies suggest that customer delight is about a pleasant surprise experienced by customers during a service process (Oliver et al., 1997; Berman, 2005; McNeilly, \& Barr, 2006; 
Barnes et al., 2014). We argue that some local foods in Yogyakarta are able to provide a pleasant surprise element to tourists due to their unique local ingredients and variety of tastes.

Our research is able to prove that local food enjoyment has a positive effect on revisit intention (H2). Previous studies have noted that local foods can provide positive and authentic experiences and promote togetherness when shared during the trips (Kim et al., 2009; Jung et al., 2015; Chairy and Syahrivar, 2019). We argue that positive feelings and memories with regard to local food experiences may promote place attachment (Ji \& Prentice, 2021) and trigger the desire to return in the future.

Our research is able to prove customer delight has a positive effect on revisit intention (H3a). In other words, pleasant and positive surprises that visitors of Yogyakarta encountered during their trips may motivate them to revisit the place. The finding adds a weight of evidence on the relationship between delight and intention as also demonstrated by the previous studies, such as Loureiro and Kastenholz (2011) and Kim et al. (2015).

Finally, our research can prove that customer delight (partially) mediates the relationship between local food enjoyment and revisit intention (H3b). It means that customer delight can also explain why tourists want to return to a tourist site after tasting the local cuisine. When tourists enjoy local foods, some may experience a positive and pleasant surprise hence customer delight. The customer delight that they experienced during the culinary trips may improve the desire to return to Yogyakarta in the future.

We wish to highlight several limitations of this research. First, this research was conducted during the COVID-19 pandemic. Different behavioural patterns might occur that affected the results of this research. Future research may investigate the relationships we have proposed and proven in this research in the post-pandemic era. Second, the results of this research are limited to Yogyakarta. Second, we recognized that several tourism destinations in Indonesia may not be wellknown for their culinary specialities, so their "pleasant surprise" elements may differ.

\section{CONCLUSION AND SUGGESTION}

This research is able to prove all its hypotheses. The results of this research reveal that local food enjoyment is a positive predictor of customer delight. The results also reveal that both local food enjoyment and customer delight are positive predictors of revisit intention. Lastly, the results suggest that customer delight partially mediates the relationship between local food enjoyment and revisit intention.

Amid the COVID-19 pandemic that devastated Indonesia (Purnomo et al., 2021; Syahrivar, 2021), the local government must improve local community resilience through several alternative tourism strategies, such as culinary tourism (Horng \& Tsai, 2010). Culinary tourism, which introduces customers to local and traditional foods, may increase customer delight, resulting in a place attachment, such as a desire to return. Culinary tourism may improve local pride (e.g. local products first) and togetherness that are highly needed to overcome multidimensional issues that emerged during the pandemic. Moreover, exceeding customers' expectations is of paramount importance in the tourism industry. Surprise elements to bring about memorable tourism experiences is pivotal in the overall strategies to attract tourists. 


\section{REFERENCES}

Adrianty, O. N., \& Chairy, C. (2021). Factors affecting tourist revisit intention in Bali. Jurnal Muara Ilmu Ekonomi dan Bisnis, 5(1), 171-178. https://doi.org/10.24912/jmieb.v5i1.10977

Ajzen, I., \& Fishbein, M. (1980). Understanding attitudes and predicting social behavior, Englewood Cliffs, NJ: Prentice-Hall.

Arsil, P., Li, E., \& Bruwer, J. (2014). Perspectives on consumer perceptions of local foods: a view from Indonesia. Journal of International Food and Agribusiness Marketing, 26(2), 107-124. https://doi.org/10.1080/08974438.2012.755725

Barnes, D.C., Collier, J.E., \& Robinson, S. (2014). Customer delight and work engagement. Journal of Services Marketing, 28(5), 380-390. https://doi.org/10.1108/JSM-02-2013-0051

Berman, B. (2005). How to delight your customers. California Management Review, 48(1), 129151. https://journals.sagepub.com/doi/pdf/10.2307/41166331

Chairy, C. \& Syahrivar, J. (2019). Bika Ambon of Indonesia: history, culture, and its contribution to tourism sector. Journal of Ethnic Foods, 6(2), 1-6. https://doi.org/10.1186/s42779-0190006-6

Chairy, C., Raharja, C., Syahrivar, J., \& Ekananda, M. (2020). Waste not: selling near-expired bread in Indonesia. International Review on Public and Nonprofit Marketing, 17(4), 391407. https://doi.org/10.1007/s12208-020-00253-4

Crotts, J. C., Pan, B., \& Raschid, A. E. (2008). A survey method for identifying key drivers of guest delight. International Journal of Contemporary Hospitality Management, 20(4), $462-$ 470. https://doi.org/10.1108/09596110810873552

Dusoruth, V., Peterson, H.H., \& Schmitt, J. (2018). Estimating a local food waste baseline. Journal of Food Products Marketing, 24(5), 654-680. https://doi.org/10.1080/10454446.2018.1472698

Finn, A. (2005). Reassessing the foundations of customer delight. Journal of Service Research, 8(2), 103-116. https://doi.org/10.1177/1094670505279340

Goswami, S., \& Sarma, M. K. (2019). Modelling customer delight in hotel industry. Global Business Review, 20(2), 405-419. https://doi.org/10.1177/0972150918825396

Hair, J. F., Risher, J. J., Sarstedt, M., \& Ringle, C. M. (2019). When to use and how to report the results of PLS-SEM. European Business Review, 31(1), 2-24. https://doi.org/10.1108/EBR11-2018-0203

Henseler, J., Hubona, G., \& Ray, P. A. (2016). Using PLS path modeling in new technology research: updated guidelines. Industrial Management and Data Systems, 116(1), 2-20. https://doi.org/10.1108/IMDS-09-2015-0382

Horng, J. S., \& Tsai, C. T. S. (2010). Government websites for promoting East Asian culinary tourism: A cross-national analysis. Tourism Management, 31(1), 74-85. https://doi.org/10.1016/j.tourman.2009.01.009

Islamiyati, D., \& Chairy, C. (2021). the Influence of Memorable Souvenirs Shopping Experience and Place Identity on Revisit Intention (the Case of Yogyakarta). Jurnal Muara Ilmu Ekonomi dan Bisnis, 5(1), 205-213. https://doi.org/10.24912/jmieb.v5i1.11054

Ji, C., \& Prentice, C. (2021). Linking transaction-specific satisfaction and customer loyalty-the case of casino resorts. Journal of Retailing and Consumer Services, 58, 102319. https://doi.org/10.1016/i.jretconser.2020.102319

Jung, T., Ineson, E.M., Kim, M., \& Yap, M.H. (2015). Influence of festival attribute qualities on Slow Food tourists' experience, satisfaction level and revisit intention: The case of the Mold Food and Drink Festival. Journal of Vacation Marketing, 21(3), 277-288. https://doi.org/10.1177/1356766715571389 
Kim, M., Vogt, C. A., \& Knutson, B. J. (2015). Relationships among customer satisfaction, delight, and loyalty in the hospitality industry. Journal of Hospitality and Tourism Research, 39(2), 170-197. https://doi.org/10.1177/1096348012471376

Kim, S. B., Sun, K. A., \& Kim, D. Y. (2013). The influence of consumer value-based factors on attitude-behavioral intention in social commerce: The differences between high-and lowtechnology experience groups. Journal of Travel and Tourism Marketing, 30(1-2), 108-125. https://doi.org/10.1080/10548408.2013.751249

Kim, Y.G., Eves, A., \& Scarles, C. (2009). Building a model of local food consumption on trips and holidays: A grounded theory approach. International Journal of Hospitality Management, 28(3), 423-431. https://doi.org/10.1016/j.ijhm.2008.11.005

Loureiro, S.M.C., \& Kastenholz, E. (2011). Corporate reputation, satisfaction, delight, and loyalty towards rural lodging units in Portugal. International Journal of Hospitality Management, 30(3), 575-583. https://doi.org/10.1016/j.ijhm.2010.10.007

McDaniel, T., Soto Mas, F., \& Sussman, A. L. (2021). Growing Connections: Local Food Systems and Community Resilience. Society and Natural Resources, 1-19. https://doi.org/10.1080/08941920.2021.1958965

McNeilly, K.M., \& Barr, T.F. (2006). I love my accountants-they're wonderful: understanding customer delight in the professional services arena. Journal of Services Marketing, 20(3), 152-159. https://doi.org/10.1108/08876040610665607

Nakamura, E.M., \& Hanazaki, N. (2017). Protected area establishment and its implications for local food security. Human Ecology Review, 23(1), 101-122. https://www.jstor.org/stable/26367966

Oliver, R.L., Rust, R.T., \& Varki, S. (1997). Customer delight: foundations, findings, and managerial insight. Journal of Retailing, 73(3), 311-336. https://doi.org/10.1016/S00224359(97)90021-X

Purnomo, B. R., Adiguna, R., Widodo, W., Suyatna, H., \& Nusantoro, B. P. (2021). Entrepreneurial resilience during the Covid-19 pandemic: navigating survival, continuity and growth. Journal of Entrepreneurship in Emerging Economies, 13(4), 497-524. https://doi.org/10.1108/JEEE-07-2020-0270

Rianingrum, C. J., Sachari, A., \& Widodo, P. (2014). Tradition concept in Kauffman Yogyakarta settlement as a representation of Javanese cultural values. Arts and Design Studies, 21, $22-$ 30.

Sambodo, A. P., \& Utami, D. W. (2019, November). Potential Use of Student's Travel Pattern for Integrated Transportation System Planning in Yogyakarta. In ASEAN/Asian Academic Society International Conference Proceeding Series (pp. 442-447).

Su, W. S., Hsu, C. C., Huang, C. H., \& Chang, L. F. (2018). Setting attributes and revisit intention as mediated by place attachment. Social Behavior and Personality: an international journal, 46(12), 1967-1981. https://doi.org/10.2224/sbp.6861

Syahrivar, J., Genoveva, G., Chairy, C., \& Manurung, S. P. (2021). COVID-19-Induced Hoarding Intention Among the Educated Segment in Indonesia. SAGE Open, 11(2), 21582440211016904. https://doi.org/10.1177/21582440211016904

Taber, K. S. (2018). The use of Cronbach's alpha when developing and reporting research instruments in science education. Research in Science Education, 48(6), 1273-1296. https://doi.org/10.1007/s11165-016-9602-2

Tsai, C.T.S., \& Wang, Y.C. (2017). Experiential value in branding food tourism. Journal of Destination Marketing and Management, 6(1), 56-65. https://doi.org/10.1016/j.jdmm.2016.02.003 
Wijaya, S. (2019). Indonesian food culture mapping: a starter contribution to promote Indonesian culinary tourism. Journal of Ethnic Foods, 6(1), 1-10. https://doi.org/10.1186/s42779-019$\underline{0009-3}$

Yusuf, M. (2017). Measuring tourist's motivations for consuming local Angkringan street food in Yogyakarta, Indonesia. Journal of Indonesian Tourism and Development Studies, 5(2), $65-$ 72. https://doi.org/10.21776/ub.jitode.2017.005.02.01 